CLINICAL STUDY

\title{
GH and IGF1 levels are positively associated with musculotendinous collagen expression: experiments in acromegalic and GH deficiency patients
}

Simon Doessing, Lars Holm, Katja M Heinemeier, Ulla Feldt-Rasmussen ${ }^{1}$, Peter Schjerling, Klaus Qvortrup ${ }^{2}$, Jytte O Larsen ${ }^{3}$, Rie H Nielsen, Allan Flyvbjerg ${ }^{4}$ and Michael Kjaer

Department of Orthopaedic Surgery M, Faculty of Health Sciences, Institute of Sports Medicine, Bispebjerg Hospital and Centre for Healthy Aging, University of Copenhagen, Bispebjerg Bakke 23, Copenhagen DK-2400, Denmark, ${ }^{1}$ Department of Endocrinology, Copenhagen University Hospital Rigshospitalet, Copenhagen DK-2100, Denmark, ${ }^{2}$ Department of Biomedical Sciences, Faculty of Health Sciences and ${ }^{3}$ Department of Neuroscience and Pharmacology, University of Copenhagen, Copenhagen DK-2200, Denmark and ${ }^{4}$ Department of Endocrinology and Internal Medicine and the Medical Research Laboratories, Clinical Institute, Aarhus University Hospital, Aarhus DK-8000, Denmark

(Correspondence should be addressed to S Doessing; Email: simondoessing@gmail.com)

\begin{abstract}
Objective: Disproportionate growth of musculoskeletal tissue is a major cause of morbidity in both acromegalic (ACRO) and GH-deficient (GHD) patients. GH/IGF1 is likely to play an important role in the regulation of tendon and muscle collagen. We hypothesized that the local production of collagen is associated with the level of GH/IGF1.

Design and methods: As primary outcomes, collagen mRNA expression and collagen protein fractional synthesis rate (FSR) were determined locally in skeletal muscle and tendon in nine ACRO and nine GHD patients. Moreover, muscle myofibrillar protein synthesis and tendon collagen morphology were determined.

Results and conclusions: Muscle collagen I and III mRNA expression was higher in ACRO patients versus GHD patients $(P<0.05)$, whereas collagen protein FSR did not differ significantly between ACRO and GHD patients in muscle $(P=0.21)$ and tendon $(P=0.15)$. IGF1E $a$ and IGF1Ec mRNA expression in muscle was higher in ACRO patients versus GHD patients $(P<0.01)$. Muscle IGF1Ea mRNA expression correlated positively with collagen I mRNA expression $(P<0.01)$. Tendon collagen fibrillar area tended to be higher in GHD patients relative to ACRO patients $(P=0.07)$. Thus, we observed a higher expression for collagen and IGF1 mRNA in local musculotendinous tissue in ACRO patients relative to GHD patients. Moreover, there was a tendency towards a higher collagen protein FSR and a smaller collagen fibril diameter in ACRO patients relative to GHD patients. The results indicate a collagenstimulating role of local IGF1 in human connective tissue and add to the understanding of musculoskeletal pathology in patients with either high or low GH/IGF1 axis activity.
\end{abstract}

European Journal of Endocrinology 163 853-862

\section{Introduction}

Disproportionate growth of musculoskeletal tissue is a major cause of morbidity in patients with acromegaly and GH deficiency (GHD) $(1,2)$, and symptoms from bone, joints, tendon and muscle have a major impact on the quality of life in both patient groups (3-6). GH and insulin-like growth factor 1 (IGF1) play an important role in the regulation of protein synthesis, including collagen and myofibrillar protein, the two most abundant proteins in musculoskeletal tissues. However, the possible effect of altered GH/IGF1 levels on the synthesis of collagen and myofibrillar protein has not been determined locally in musculoskeletal tissues in patients with acromegaly and GHD.

Acral overgrowth of hands and feet and coarsened facial features in acromegalic patients (7) suggest an association between GH/IGF1 and the production of collagen. Moreover, indirect measures of whole-body collagen synthesis appear to correlate with circulating GH/IGF1 and respond to hormone-regulating treatment (8). It is, however, presently unknown whether collagen protein synthesis in specific musculoskeletal tissues correlates with the level of GH/IGF1 years after remission. This is clinically relevant, because the detrimental effect of prior $\mathrm{GH}$ excess on musculoskeletal tissue is not fully reversible by hormoneregulating treatment (1), a finding that questions the association between GH/IGF1 and collagen. Moreover, it remains to be established to what extent the level of GH/IGF1 affects the synthesis of collagen protein locally in musculoskeletal tissue of GHD individuals, as suggested by the observed increase in collagen gene 
expression of hypopituitary men after short-term GH supplementation (9).

Locally produced IGF1 is gaining attention as a possible key regulator of musculoskeletal protein synthesis $(10,11)$, and short-term GH supplementation was associated with increased IGF1 mRNA expression in skeletal muscle in both normoendocrine participants and GHD patients $(9,12)$. It is currently not known how chronically altered GH levels may affect the local expression of musculoskeletal IGF1 isoforms in acromegalic patients, and importantly, how well local IGF1 expression and local collagen expression are associated in these patients.

Collagen morphology is a major determinant of the mechanical properties in tissues such as bone and tendon. One study in GHD rats suggested that bone collagen fibril diameter and $\mathrm{GH}$ levels were inversely correlated (13), which could in part explain the high incidence of bone fractures seen in GHD patients (14). However, a possible association between GH/IGF1 titre and collagen fibril diameter is unexplored in man.

GH/IGF1 excess clearly yields a muscle anabolic effect in growing animals (15-18), whereas myofibrillar protein synthesis in healthy human adults appear to be unaffected by supplementation of GH $(12,19,20)$. In acromegalic patients, excess $\mathrm{GH}$ does not result in increased muscle mass or strength (21-23), while the observed increase in muscle strength and endurance experienced by GHD patients following GH treatment appear to be a result of altered metabolic functions as well as a stimulation of protein synthesis, suppression of protein oxidation and increased muscle mass (24-27). Taken together, it is currently not clear whether GH/IGF1 and skeletal muscle myofibrillar protein synthesis are positively correlated in man, but investigating both acromegalic and GHD patients offers a unique possibility to address this question.

In this study, we hypothesized that the level of GH/IGF1 in acromegalic and GHD patients is positively associated with collagen synthesis in tendon and muscle, whereas the effect on myofibrillar protein is limited. Outcomes were collagen and IGF1 mRNA expression, as well as rate of collagen and myofibrillar protein synthesis in skeletal muscle and collagen synthesis in tendon. Moreover, quantitative collagen morphology in tendon was determined.

\section{Subjects and methods}

\section{Patients}

Eighteen male patients, nine with acromegaly $(38 \pm 9$ years) and nine with GHD (35 \pm 9 years), were recruited from the Department of Endocrinology, Copenhagen University Hospital, Rigshospitalet (Table 1). The patients gave informed consent to a protocol adhering to the Helsinki Declaration, which was approved by the
Table 1 Patient clinical characteristics.

\begin{tabular}{|c|c|c|c|}
\hline Patients & $\begin{array}{l}\text { Disease/ } \\
\text { duration } \\
\text { (years) }\end{array}$ & Treatment & $\begin{array}{c}\text { Age } \\
\text { (years) }\end{array}$ \\
\hline 1 & $\mathrm{ACRO} / 2$ & $\begin{array}{l}\text { Somatostatin analogue } \\
\text { (20 mg/4 weeks) }\end{array}$ & 31 \\
\hline 2 & ACRO/0 & $\begin{array}{l}\text { Somatostatin analogue } \\
(20 \mathrm{mg} / 2 \text { weeks })\end{array}$ & 31 \\
\hline 3 & $\mathrm{ACRO} / 7$ & $\begin{array}{l}\text { Surgery + somatostatin } \\
\quad \text { analogue ( } 30 \mathrm{mg} / 4 \text { weeks) }\end{array}$ & 32 \\
\hline 4 & $\mathrm{ACRO} / 6$ & $\begin{array}{l}\text { Surgery + somatostatin } \\
\quad \text { analogue ( } 30 \mathrm{mg} / 3 \text { weeks) }\end{array}$ & 32 \\
\hline 5 & $\mathrm{ACRO} / 1$ & $\begin{array}{l}\text { Somatostatin analogue } \\
\text { (20 mg/4 weeks) }\end{array}$ & 33 \\
\hline 6 & $\mathrm{ACRO} / 2$ & $\begin{array}{l}\text { Surgery + somatostatin } \\
\quad \text { analogue (10 mg/4 weeks) }\end{array}$ & 37 \\
\hline 7 & $\mathrm{ACRO} / 6$ & Surgery & 47 \\
\hline 8 & ACRO/6 & $\begin{array}{l}\text { Somatostatin analogue } \\
(20 \mathrm{mg} / 4 \text { weeks })\end{array}$ & 49 \\
\hline 9 & $\mathrm{ACRO} / 2$ & $\begin{array}{l}\text { Surgery + somatostatin } \\
\quad \text { analogue (10 mg/4 weeks) }\end{array}$ & 52 \\
\hline 10 & $\mathrm{GHD} / 1$ & $\mathrm{GH}$ (0.3 mg/day) & 21 \\
\hline 11 & $\mathrm{GHD} / 4$ & GH (0.2 mg/day) & 28 \\
\hline 12 & $\mathrm{GHD} / 3$ & GH (0.8 mg/day) & 30 \\
\hline 13 & $\mathrm{GHD} / 5$ & GH (0.4 mg/day) & 32 \\
\hline 14 & GHD/3 & $\mathrm{GH}$ (0.6 mg/day) & 32 \\
\hline 15 & $\mathrm{GHD} / 3$ & GH (0.2 mg/day) & 38 \\
\hline 16 & $\mathrm{GHD} / 8$ & GH (0.6 mg/day) & 39 \\
\hline 17 & $\mathrm{GHD} / 8$ & GH (0.5 mg/day) & 43 \\
\hline 18 & $\mathrm{GHD} / 7$ & GH (0.6 mg/day) & 50 \\
\hline
\end{tabular}

Ethics Committee of Copenhagen and Frederiksberg (KF-01-241/03). Upon recruitment, the patients had been involved in hormone-regulating treatment for 4 years $( \pm 2$ years). All nine GHD patients received GH substitution when included, but were withdrawn from the treatment 2 weeks prior to the study in order to bring the patients closer to a state of GHD. The number of patients who accepted the invasive protocol was limited, and consequently the patient groups displayed heterogeneity with regards to duration of disease, prior treatment strategies and present hormone-regulating treatment. The present study therefore focused strictly on the association between GH/IGF1 titre and collagen/myofibrillar protein synthesis measured at a single time point.

Nine healthy age-matched male participants were included as controls with regards to circulating GH, IGF1, and IGF-binding protein (IGFBP) levels.

\section{Tissue biopsy procedure}

Biopsies were taken in a post-absorptive state $(10 \mathrm{~h}$ fasting). The sample sites were prepared with local anaesthetics (lidocaine, 1\%), and tendon and muscle were sampled from the non-dominant leg. Tendon samples were taken from the patella tendon (Bard Magnum Biopsy Instrument, C R Bard, Inc., Covington, GA, USA) with a $14 \mathrm{~g}$ needle (28). The total wet weight of each tendon sample was from 5 to $10 \mathrm{mg}$. Half of the tendon biopsy was frozen in liquid nitrogen and stored 
at $-80{ }^{\circ} \mathrm{C}$ and subsequently used for protein fractional synthesis rate (FSR) analysis, while the other half was fixed in $2 \%$ glutaraldehyde in $0.05 \mathrm{M}$ sodium phosphate buffer, $\mathrm{pH}$ 7.4, for transmission electron microscopy (TEM) analysis. Muscle was sampled from the vastus lateralis (m. quadriceps) muscle using a $5 \mathrm{~mm}$ Bergström biopsy needle (Stille, Stockholm, Sweden) with suction (29). The total wet weights of the muscle samples were from 50 to $80 \mathrm{mg}$. Muscle samples were divided and frozen in liquid nitrogen and stored at $-80{ }^{\circ} \mathrm{C}$ for subsequent mRNA expression and FSR analysis. In order to establish tissue natural abundance of $\left[1-{ }^{13} \mathrm{C}\right]$ proline for determination of FSR, a skin biopsy was obtained with a $4 \mathrm{~mm}$ Dermal Biopsy Punch (Miltex, Inc., York, PA, USA) from the back, frozen in liquid nitrogen and stored at $-80{ }^{\circ} \mathrm{C}$.

\section{Muscle mRNA measurements}

The amount of mRNA for collagen isoforms $\alpha 1(\mathrm{I})$ (COL1A1) and $\alpha 1$ (III) (COL3A1), as well as IGF1 isoforms IGF1Ea and IGF1Ec, was measured with realtime RT-PCR (Table 2). Muscle was homogenized in TriReagent (Molecular Research Centre, Cincinnati, OH, USA) using a bead mixer with steel beads (Biospec Products, Bartlesville, OK, USA). Following homogenization, bromochloropropane (Molecular Research Centre) was added in order to separate the samples into an aqueous and an organic phase. Following isolation of the aqueous phase, RNA was precipitated using isopropanol, washed in ethanol and dissolved in RNAse-free water. All muscle samples were weighed prior to RNA extraction. RNA concentrations were determined by spectroscopy, and good RNA quality was ensured by gel electrophoresis.

Synthesis of cDNA was performed using the Omniscript reverse transcriptase (Qiagen) on $500 \mathrm{ng}$ of RNA in $20 \mu \mathrm{l}$. For each target mRNA, $0.25 \mu \mathrm{l}$ cDNA was amplified in $25 \mu$ l Quantitect SYBR Green Master Mix (Qiagen) with specific primers (100 nM each, Table 1) on a real-time PCR machine (MX3000P, Stratagene, La Jolla, CA, USA). The thermal profile was $95^{\circ} \mathrm{C}$, $10 \mathrm{~min} \rightarrow\left(95^{\circ} \mathrm{C}, \quad 15 \mathrm{~s} \rightarrow 58{ }^{\circ} \mathrm{C}, \quad 30 \mathrm{~s} \rightarrow 63{ }^{\circ} \mathrm{C}, \quad 90 \mathrm{~s}\right)$ $\times 50 \rightarrow 95{ }^{\circ} \mathrm{C}, 60 \mathrm{~s} \rightarrow 55^{\circ} \mathrm{C}, 30 \mathrm{~s} \rightarrow 95^{\circ} \mathrm{C}, 60 \mathrm{~s}$. Signal intensity was acquired at the $63{ }^{\circ} \mathrm{C}$ step, and the threshold cycle $\left(C_{\mathrm{t}}\right)$ values were related to a standard curve made with the cloned PCR product. Specificity was confirmed by melting curve analysis after amplification (the 55 to $95{ }^{\circ} \mathrm{C}$ step). We analysed the tissue samples for both IGF1Ea and IGF1Ec. A 49 bp insertion in IGF1Ec makes this isoform distinguishable from IGF1Ea. In the IGF1Ea assay, the sense primer was placed over the insertion point ensuring that the last two bases fitted downstream of the insertion point. This creates a single base mismatch between IGF1Ea and IGF1Ec in the $3^{\prime}$ end (...GGA-3' in IGF1Ea versus...GTA-3' in IGF1Ec), which should inhibit amplification from IGF1Ec cDNA (30). Indeed, there was no amplification of the 49 bp larger IGF1Ec isoform in the IGF1Ea assay, based on agarose gel and melting curve analysis. For the IGF1Ec assay, the sense primer was placed in the IGF1Ec-specific insertion. The large ribosomal protein PO (RPLPO) mRNA, which was stably expressed relative to both GAPDH mRNA and total RNA (data not shown), was chosen as an internal control.

\section{Collagen and myofibrillar protein FSR}

Measurement of collagen protein FSR was carried out according to previous techniques (31). Skin biopsy was used to establish the natural abundance of $\left[1-{ }^{13} \mathrm{C}\right]$ proline in collagen protein, thereby eliminating the need for a pre-infusion basal tissue biopsy. To label collagen protein in muscle and tendon, a flooding dose of $\left[1-{ }^{13} \mathrm{C}\right]$ proline ( $1 \mathrm{~g}$ labelled proline ( $>99$ atoms\%, Cambridge Isotope Laboratory, Andover, MA, USA) plus $3 \mathrm{~g}$ unlabelled proline (AppliChem, Darmstadt, Germany), $4 \mathrm{~g}$ total) was given. Blood samples were drawn every 10-30 min during the $2 \mathrm{~h}$ experiment to establish area under the curve (AUC) for the precursor.

For extraction of proteins, all tissues were homogenized (FastPrep 120A-230, Thermo Savant, Holbrook, $\mathrm{NY}$, USA) in $1 \mathrm{ml}$ ice-cold extraction buffer $(0.02 \mathrm{M}$ Tris-HCl, 0.15 M NaCl, 0.1 M EDTA and 0.1\% Triton $\mathrm{X}-100, \mathrm{pH} 7.4$ ) and subsequently centrifuged (1600 g at $4{ }^{\circ} \mathrm{C}$ for $20 \mathrm{~min}$ ). In skin and tendon samples, this procedure pelleted the total collagen protein fraction. The pellets were then washed twice with $70 \%$ ethanol. In muscle samples, the homogenization procedure pelleted the myofibrillar and collagen proteins. After discarding the supernatant, the pellet was resuspended in $0.7 \mathrm{M} \mathrm{KCl}$, in which the myofibrillar proteins

Table 2 Primers for real-time RT-PCR.

\begin{tabular}{llll}
\hline mRNA & Sense & Antisense & GenBank accession number \\
\hline IGF1Ea $^{a}$ & GACATGCCCAAGACCCAGAAGGA & CGGTGGCATGTCACTCTTCACTC & NM_00618.3 \\
IGF1EC & GCCCCCATCTACCAACAAGAACAC & CGGTGGCATGTCACTCTTCACTC & NM_001111283.1 \\
COL1A1 & GGCAACAGCCGCTTCACCTAC & GCGGGAGGACTTGGTGGTTT & Z74615.1 \\
COL3A1 & CACGGAAACACTGGTGGACAGATT & ATGCCAGCTGCACATCAAGGAC & NM_000090.3 \\
GAPDH & CCTCCTGCACCACCAACTGCTT & GAGGGGCCATCCACAGTCTTCT & NM_002046.3 \\
RPLPO & GGAAACTCTGCATTCTCGCTTCCT & CCAGGACTCGTTTGTACCCGTTG & NM_053275.3
\end{tabular}

${ }^{\text {a }}$ The IGF1EC-specific 49 bp insertion (58) is discriminated by an insertion-specific sense primer (IGF1EC) versus an insertion point overlapping (last two $3^{\prime}$ bases) sense primer (IGF1Ea). 
solubilize and the collagen proteins remain precipitated. After centrifugation $\left(1600 \mathrm{~g}\right.$ at $4{ }^{\circ} \mathrm{C}$ for $\left.20 \mathrm{~min}\right)$, the myofibrillar proteins were precipitated from the supernatant using $2.3 \times$ vol. ice-cold ethanol and left at $4{ }^{\circ} \mathrm{C}$ for $1 \mathrm{~h}$. After pelleting the myofibrillar proteins $(1600 \mathrm{~g}$ at $4{ }^{\circ} \mathrm{C}$ for $20 \mathrm{~min}$ ), the myofibrillar protein fraction was washed twice with $70 \%$ ethanol. All isolated protein fractions were hydrolysed in $6 \mathrm{M} \mathrm{HCl}$ at $110^{\circ} \mathrm{C}$ overnight, and the amino- and imino acids were purified using cation exchanger (Dowex 50WX8, Bio-Rad) and eluted by $2 \mathrm{M} \mathrm{NH}_{4} \mathrm{OH}$. The amino- and imino acids were derivatized as their $N$-acetyl- $n$-propyl esters, which were analysed by capillary gas chromatography-combustion-isotope ratio mass spectrometry (GC-C-IRMS; Delta Plus XL, Thermo Finnigan, Bremen, Germany) using a capillary column DB 1701, $30 \mathrm{~m} \times 0.25 \mathrm{~mm}$, $1.5 \mu \mathrm{m}$ film (J\&W Scientific, Agilent Technologies, Santa Clara, CA, USA) to separate proline. Plasma-free proline was derivatized as their tert-butyldimethylsilyl derivative according to standard procedures and analysed by GC-MS (Trace GC 2000 and Automass Multi, Thermo Quest Finnigan, Paris, France) using a capillary column CP-Sil 8 low bleed, $30 \mathrm{~m} \times 0.32 \mathrm{~mm}$, $0.25 \mu \mathrm{m}$ column (Chrompack, Varian, Palo Alto, CA, USA). The rate of tissue protein synthesis was calculated according to the precursor-product principle as follows: fractional protein synthesis $(\mathrm{FSR} \% / \mathrm{h})=\Delta E_{\mathrm{p}} \times 100 / \mathrm{AUCp}$; where $\Delta E_{\mathrm{p}}$ is the change in proline labelling over time in tissue protein, and AUCp is the AUC of venous proline labelling with time in hours.

\section{Transmission electron microscopy and stereological analysis of tendon}

Fixed tendon samples were rinsed in $0.15 \mathrm{M}$ sodium cacodylate buffer, $\mathrm{pH} 7.4$, and post-fixed for $2 \mathrm{~h}$ in $1 \%$ $\mathrm{OsO}_{4}$ in $0.12 \mathrm{M}$ sodium cacodylate buffer, $\mathrm{pH}$ 7.4. The samples were dehydrated in graded series of ethanol, transferred to propylene oxide and embedded in Epon (Hexion, Houston, TX, USA) according to standard procedures. Ultra thin sections were cut with a ReichertJung Ultracut E microtome and collected on Formvar membranes. Sections were stained with uranyl acetate and lead citrate and examined with a Philips CM 100 TEM $(80 \mathrm{kV})$ equipped with a SIS MegaView 2 camera. Digital images were recorded with the analySIS software package.

From each biopsy cross section, ten randomly sampled electron micrographs were recorded and subsequently analysed stereologically (C.A.S.T.-grid software, The International Stereology Center at Olympus, Denmark) to quantify the individual fibril diameter and area, as well as the cross-sectional number of fibrils per area as described previously $(32,33)$.

\section{Hormone assays}

Blood samples drawn from the antecubital vein were separated $\left(3200 \mathrm{~g}\right.$ at $\left.4{ }^{\circ} \mathrm{C}\right)$, and serum was stored at
$-80{ }^{\circ} \mathrm{C}$. Serum GH (sGH) and serum IGF1 (sIGF1) concentrations were determined by a time-resolved immunofluorometric assay (Perkin Elmer, Turku, Finland). Serum IGFBP-1 (sIGFBP-1) was determined by an in-house RIA as described previously (34). sIGFBP-3 was measured by a commercially available IRMA (BioSource Europe, Nivelles, Belgium). All assays had intra- and inter-assay coefficients of variation below 5 and $10 \%$ respectively.

\section{Statistical analysis}

Using SigmaStat 3.5 (Systat Software, Inc., San Jose, CA, USA), differences between acromegalic and GHD patients were tested with unpaired, two-sided $t$-tests. Outcome was the difference between patient groups with 95\% confidence interval (CI) and significance level $(P$ value). Pearson's correlation analysis was used to determine baseline correlation between systemic IGF1/local IGF1 mRNA and collagen mRNA. Patient characteristics are presented as mean \pm s.D. All other results are presented as mean \pm s.E.M. mRNA data were log-transformed before statistical analysis and are presented as geometric mean \pm back-transformed s.E.M. Differences were considered significant when $P<0.05$.

\section{Results}

\section{Systemic GH, IGF1 and IGFBP}

Relative to age-matched controls, the acromegalic patient group had higher levels of sGH, sIGF1 and sIGFBP-3, while the GHD patient group had lower levels of sGH, sIGF1 and sIGFBP3 compared to healthy participants (all $P<0.05$; Table 3). sGH was 30-fold (95\% CI: 13; 46; $P<0.01$ ) higher in acromegalic patients compared with GHD patients, and sIGF1 was 2.9-fold higher (95\% CI: $1.5 ; 4.3 ; P<0.01)$ in acromegalic patients relative to GHD patients. sIGFBP3 was 1.4 -fold (95\% CI: $1.2 ; 1.5 ; P<0.01$ ) higher in acromegalic patients compared to GHD patients, whereas sIGFBP1 did not differ between patient groups $(P=0.50)$ nor between acromegalic/GHD patients and controls $(P=0.13$ and 0.40 respectively; Table 3$)$.

Table 3 Levels of serum GH, insulin-like growth factor 1 (IGF1), IGF binding protein 1 (IGFBP1) and IGFBP3. Data are means \pm S.E.M.

\begin{tabular}{lccc}
\hline & $\begin{array}{c}\text { GH-deficient } \\
\text { patients }\end{array}$ & $\begin{array}{c}\text { Age-matched } \\
\text { controls }\end{array}$ & $\begin{array}{c}\text { Acromegalic } \\
\text { patients }\end{array}$ \\
\hline $\mathrm{sGH}(\mu \mathrm{g} / \mathrm{l})$ & $0.16 \pm 0.05$ & $0.72 \pm 0.26^{*, \dagger}$ & $2.40 \pm 0.47^{\ddagger}$ \\
$\mathrm{sIGF1}(\mu \mathrm{g} / \mathrm{l})$ & $128 \pm 15$ & $189 \pm 11^{*, \dagger}$ & $316 \pm 53^{\ddagger}$ \\
$\mathrm{sIGFBP1}(\mu \mathrm{g} / \mathrm{l})$ & $37.1 \pm 11.1$ & $33.5 \pm 2.5$ & $46.7 \pm 7.8$ \\
sIGFBP3 $(\mu \mathrm{g} / \mathrm{l})$ & $3406 \pm 157$ & $3993 \pm 151^{*, \dagger}$ & $4567 \pm 134^{\ddagger}$ \\
\hline
\end{tabular}

$n=9$ for each group. Results are compared using unpaired, two-sided $t$-test. ${ }^{*}$ Difference between controls and GH deficiency $(P<0.05)$. 'Difference between controls and acromegaly $(P<0.05)$. FDifference between $\mathrm{GH}$ deficiency and acromegaly $(P<0.01)$. 
Two weeks of discontinued GH treatment in GHD patients did not result in a change (difference between pre GHD and post GHD) in the levels of sGH, sIGF1, sIGFBP1 or sIGFBP3 (all $P>0.22$; data not shown).

\section{Local collagen expression and collagen/ myofibrillar protein synthesis}

Muscle collagen I mRNA expression was 1.7-fold (95\% CI: $1.1 ; 2.7 ; P=0.03)$ higher and muscle collagen III mRNA expression was 1.6 -fold (CI: $1.2 ; 2.1, P=0.02$ ) higher in acromegalic patients relative to GHD patients (Fig. 1C and D). Collagen protein FSR did not differ significantly between acromegalic and GHD patients in neither muscle $(P=0.21)$ nor tendon $(P=0.15$; Fig. $2 \mathrm{~A}$ and $\mathrm{B})$. Pooled muscle and tendon collagen FSR was 1.2 -fold (CI: $1.1 ; 1.4, P=0.04$ ) higher in acromegalic patients relative to GHD patients. Muscle myofibrillar protein FSR was similar in acromegalic and GHD patients $(P=0.42$; Fig. $2 \mathrm{C})$.

\section{Local IGF1 expression}

Local IGF1Ea mRNA expression in muscle was 2.5-fold (95\% CI: 1.8; 3.4; $P<0.01$ ) higher in acromegalic patients compared with GHD patients, and muscle IGF1Ec mRNA expression was 5.4-fold (95\% CI: 2.2; 13.2; $P<0.01$ ) higher in acromegalic patients relative to $\mathrm{GHD}$ patients (Fig. $1 \mathrm{~A}$ and $\mathrm{B}$ ).

\section{Collagen morphology}

There was a tendency towards a higher overall tendon collagen fibrillar area in GHD patients relative to acromegalic patients of 1.3 -fold $(95 \% \mathrm{CI}: 0.9 ; 1.7$; $P=0.07$; Fig. 3B and Fig. 4). Tendon collagen fibrillar distribution tended towards a relatively larger concentration of small collagen fibrils in acromegalic patients relative to GHD patients (Fig. 3A and Fig. 4).

\section{IGF1/collagen correlation}

Local muscle IGF1Ea mRNA expression correlated significantly with both muscle collagen I mRNA expression $\left(r^{2}=0.55, P<0.01\right)$ and muscle collagen III mRNA expression $\left(r^{2}=0.59, P<0.01\right.$; not shown). sIGF1 did not correlate significantly with either collagen I mRNA expression $\left(r^{2}=0.12, P=0.20\right)$ or collagen III mRNA expression $\left(r^{2}=0.005, P=0.79\right.$; data not shown).

\section{Average tracer to tracee ratios in plasma and tissue}

${ }^{13} \mathrm{C} /{ }^{12} \mathrm{C}$ proline was 0.18854 in plasma. In tissue, ${ }^{13} \mathrm{C} /{ }^{12} \mathrm{C}$ proline was 0.01091 in tendon collagen protein, 0.01090 in muscle collagen protein and 0.01090 in muscle myofibrillar protein.
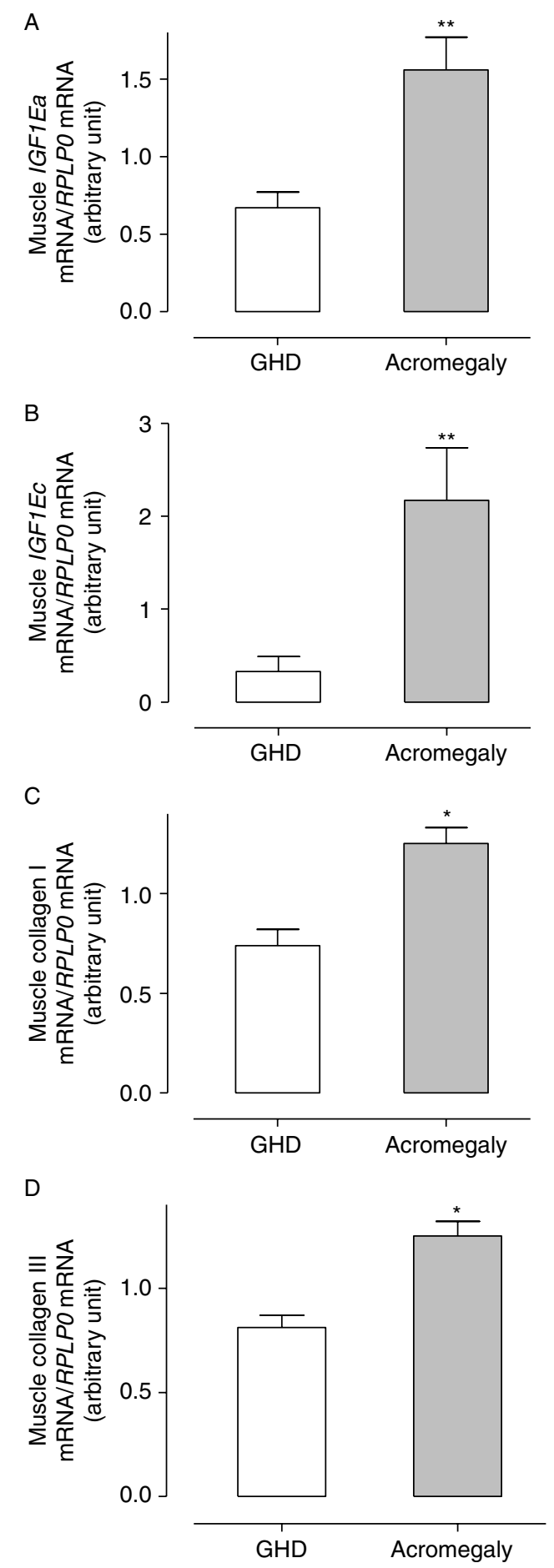

Figure 1 Skeletal muscle collagen mRNA expression. Acromegalic and $\mathrm{GH}$-deficient (GHD) patients ( $n=9$ for each patient group) were studied. Data are geometric means \pm back-transformed S.E.M. Results were compared using unpaired, two-sided $t$-test. (A) IGF1Ea mRNA; (B) IGF1Ec mRNA; (C) collagen I mRNA; (D) collagen III mRNA. *Difference between acromegalic and GHD patients $P<0.02$. ${ }^{*}$ Difference between acromegalic and GHD patients $P<0.01$. 
A
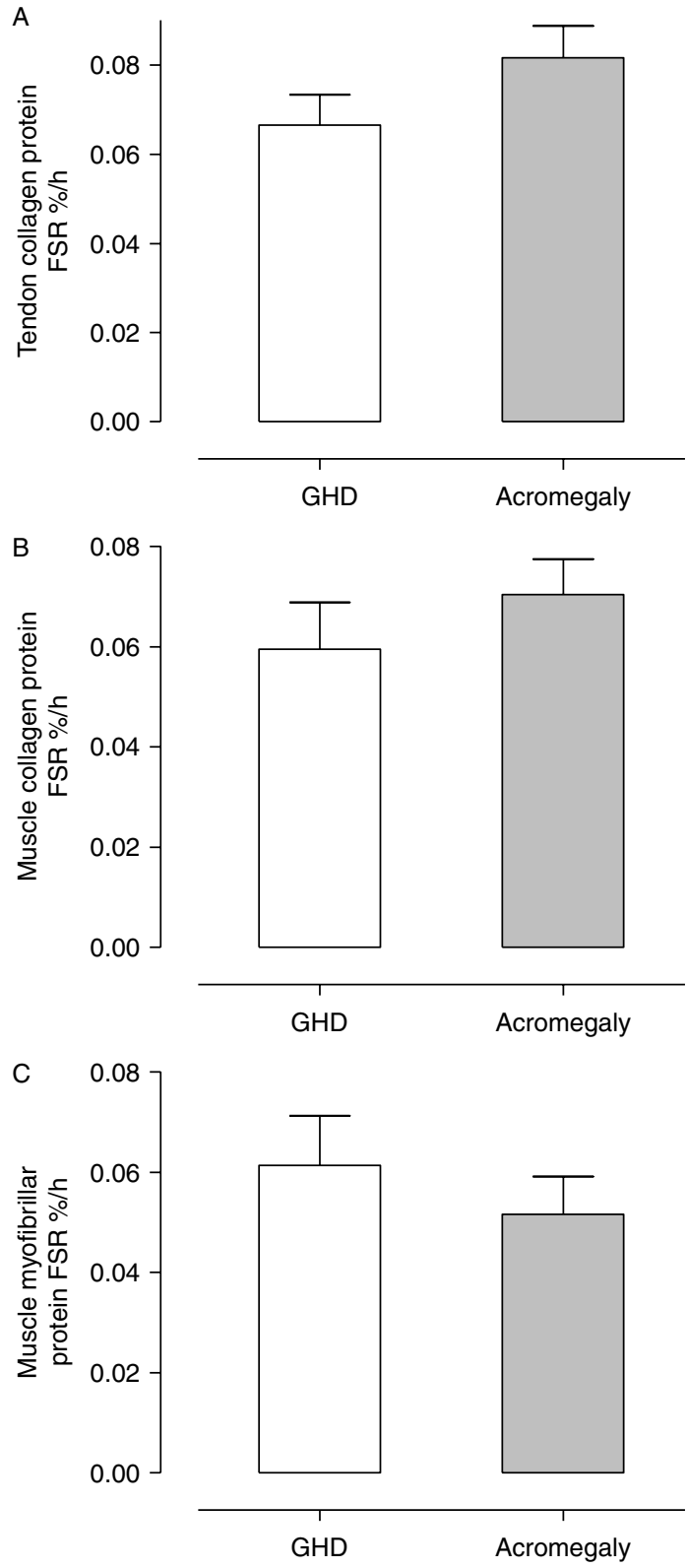

Figure 2 Skeletal muscle and tendon protein fractional synthesis rate (FSR). Acromegalic and GH-deficient (GHD) patients ( $n=9$ for each patient group) were studied. Data are means \pm s.E.M. Results were compared using unpaired, two-sided $t$-test. (A) Tendon collagen protein fractional synthesis rate; (B) muscle collagen protein fractional synthesis rate; (C) muscle myofibrillar protein fractional synthesis rate. No significant differences were seen.

\section{Discussion}

The primary finding in the present study is that higher availability of GH and IGF1 in patients with acromegaly compared with GHD patients is associated with a higher expression of collagen in skeletal muscle, and a tendency towards a higher synthesis of collagen protein in muscle and tendon. Tendon collagen fibril diameter tended towards an inverse relationship with GH/IGF1 levels, whereas the level of contractile myofibrillar protein synthesis was not associated with GH/IGF1 levels.

\section{Collagen and myofibrillar protein}

The significantly higher collagen expression observed in acromegalic patients versus GHD patients strongly suggests the involvement of GH/IGF1 in the regulation of musculoskeletal collagen production in man, and shows an increased potential for collagen synthesis in musculoskeletal tissue after years of disease despite hormone-regulating treatment. The clear differences in mRNA expression for collagen in muscle between acromegalic and GHD patients were accompanied by non-significant differences in tissue-specific collagen protein synthesis. This lack of a clear association between tissue-specific collagen mRNA and collagen protein synthesis differences is in contrast to previous observations made in healthy participants following 2 weeks of GH supplementation (12), and is likely a consequence of inherent differences in mRNA expression and protein FSR measurements. The measure of collagen synthesis, expressed as a fraction of the total collagen pool size, is only completely comparable between groups with similar collagen pool sizes (35). However, as acromegalic patients presumably have substantially larger collagen tissues compared to both healthy controls and GHD patients $(36,37)$, our data imply that despite a significantly larger collagen pool, the FSR tended to be higher in patients with acromegaly. This means a higher musculoskeletal collagen turnover rate in acromegalic patients when expressed in absolute terms. Although measuring protein synthesis as a fraction would thus seem less suitable for the type of experiment presented here,

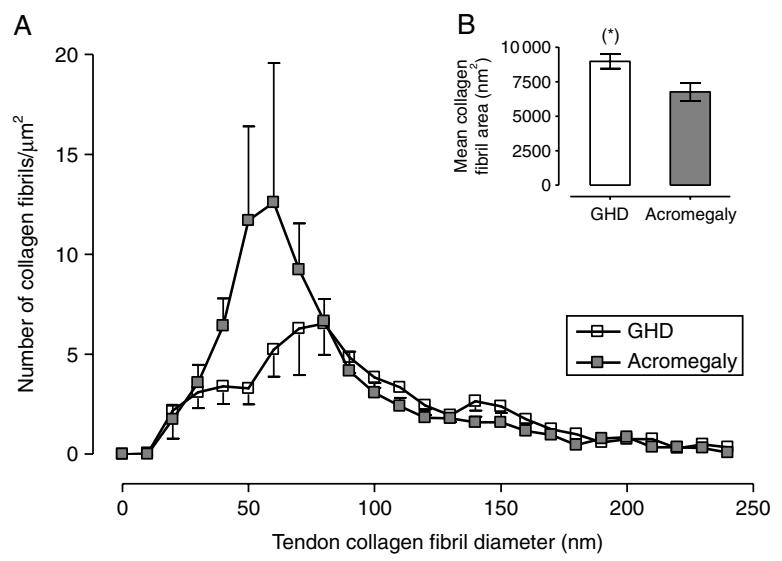

Figure 3 Quantitative tendon collagen morphology. Acromegalic and GH-deficient (GHD) patients ( $n=9$ for each patient group) were studied. Data are means \pm S.E.M. Results were compared using unpaired, two-sided $t$-test. (A) Tendon collagen fibril size distribution; (B) mean tendon collagen fibril area. *Difference between GHD and acromegaly $P=0.07$. 


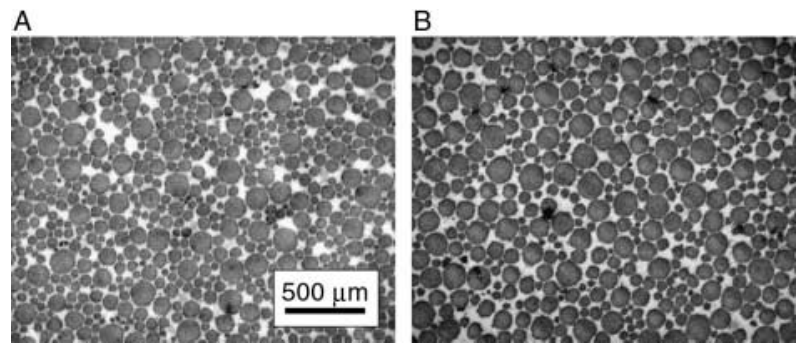

Figure 4 Transmission electron microscopy analysis of tendon. Acromegalic and GH-deficient (GHD) patients ( $n=9$ for each patient group) were studied. Images illustrate differences in collagen fibril size distribution and collagen fibril area. (A) Acromegalic patients; (B) GHD patients.

the lack of a well-established method for determining total tissue collagen pool size makes absolute collagen synthesis measurements impossible.

It cannot be excluded that compartmental nonsteady-state proline tracer dynamics can be influenced by GH/IGF1 via altered water and compartmental tissue distribution. If present, we find that this could result in an increased concentration of non-labelled proline and thus a relatively lower proline enrichment in acromegalic patients versus GHD patients, resulting in an underestimation of protein FSR in acromegalic patients relative to GHD patients.

Finally, the possibility of a type 2 error cannot be ruled out, given the relatively small number of patients in this study as well as the observation that collagen FSR was significantly higher in acromegalic patients relative to GHD patients when muscle and tendon data were pooled.

The observation that local IGF1 expression is positively correlated with local collagen expression, and is also probably associated with the absolute synthesis of collagen, is supported by in vitro studies showing a dose-dependent effect of IGF1 on collagen synthesis in animal tendon explants (38-40). However, it has to be acknowledged that the limited number of in vivo studies in animals measuring the effect of $\mathrm{GH}$ supplementation on tendon/muscle collagen synthesis have yielded somewhat conflicting results $(41,42)$. Correlations between circulating collagen propeptides (e.g. collagen I carboxyterminal propeptide (PICP)) and GH/IGF1 are observed in acromegalic and GHD patients $(43,44)$ and are compatible with our observations. However, despite commonly being described as a marker of bone-specific collagen synthesis $(43,45)$, circulating PICP measurements are clearly inconclusive regarding tissue-specific changes, such as tendon and skeletal muscle, because collagen I from other tissues likely contributes substantially to circulating PICP (46).

Myofibrillar protein synthesis was not statistically different between acromegalic and GHD patients. This was an expected result based on previous findings in healthy adult individuals $(12,19)$, and suggests that myofibrillar protein, unlike collagen, is unaffected by GH or IGF1 in fully-grown individuals (18).

There was no correlation between collagen mRNA or collagen protein synthesis and duration of disease or type of treatment in neither acromegalic nor GHD patients. Nor was collagen mRNA/protein synthesis correlated with s-testosterone (data not shown) or glucocorticoid treatment.

\section{Systemic and local levels of IGF1}

As expected, acromegalic patients had significantly higher levels of circulating GH/IGF1, and conversely, GHD patients had significantly lower levels of circulating GH/IGF1 relative to healthy controls (Table 3). This observation is of fundamental importance for the study, and confirmed that the patients differed from the normal population with respect to systemic GH/IGF1, despite being involved in hormone-regulating treatment.

We measured IGFBP1, which is believed to act as a blocker of IGF1 actions (47), as well as IGFBP3, which is thought to be a buffer for IGF1, thereby facilitating a pool of IGF1 in local tissues and thus IGF1 receptor ligand binding (48). The observation that sIGFBP1 levels were similar in both patient groups, whereas sIGFBP3 was relatively higher in acromegalic patients (Table 3), confirms previous observations $(49,50)$, and show that the final outcomes in the present study were not influenced by unexpected fluctuations in IGFBP1 and IGFBP3.

The expression of IGF1Ea and IGF1Ec mRNA in skeletal muscle was elevated in acromegalic patients compared with GHD patients (Fig. 1), suggesting that long-term elevated GH levels mediate a continuous activation of the local autocrine/paracrine IGF1 signalling system. A significant correlation between local IGF1 mRNA and collagen mRNA in muscle was demonstrated, whereas no significant correlations between sGH or sIGF1 and collagen expression were observed (data not shown). This suggests a role for local IGF1 signalling, a notion that is supported by animal studies, showing that circulating IGF1 has little effect on overall growth in mice (10), while locally produced IGF 1 is a prerequisite for GH-stimulatory effects in muscle and cartilage $(51,52)$. IGF 1 is known to induce collagen synthesis in animal tendon explants $(39,40$, 53), and in mice that overexpress human IGF1 locally, it was demonstrated that the collagen content was elevated in heart muscle (54). These findings are in accordance with our results and support the view that IGF1, rather than $\mathrm{GH}$, is directly responsible for the elevated collagen expression and protein synthesis seen in the present study. Measuring local IGF1 could prove a relevant diagnostic tool in monitoring the treatment of acromegalic and GHD patients with musculoskeletal disorders, supplementing current monitoring strategies using circulating IGF1 (55). 


\section{Quantitative collagen morphology}

There was a tendency towards smaller tendon collagen fibril area and a higher concentration of small collagen fibrils in acromegalic patients compared with GHD patients (Figs 3B and 4). This suggests that a chronically high level of GH/IGF1, with a concomitant increase in collagen expression and in absolute collagen synthesis, correlates to smaller collagen fibril area in tendon. In the only other in vivo study correlating the level of GH to collagen fibril dimensions, bone collagen fibril diameter was found to be larger in GHD rats compared to wild-type controls (13), which is in support of the observations in the present study. GH/IGF1 could potentially affect known regulators of collagen fibril diameter/area such as proteoglycans including decorin $(56,57)$. However, the effect of $\mathrm{GH}$ on fibrillar diameter/area could also be due to a consequence of changes in collagen synthesis per se, which would suggest a general negative correlation between collagen synthesis and collagen fibril diameter. It is possible that the observed association between GH/IGF1 and collagen morphology in human tendon also exists in other musculoskeletal tissues. This is interesting, given that GHD rats have significantly decreased bone strength (13), and that GHD patients suffer from a high incidence of bone fractures (14).

\section{Study design}

An important limitation of the present study design is the lack of a healthy control group to establish tissue collagen expression and synthesis in persons with normal GH/IGF1 levels. The presence of a healthy control group would clearly have allowed for a more complete understanding of the role of GH/IGF1 under physiological and pathological conditions.

\section{Conclusion and perspectives}

Our study shows that the level of circulating GH/IGF1 is positively associated with local IGF1 mRNA expression in musculotendinous tissue when comparing acromegalic and GHD patients. This indicates that a long-term elevation in GH and IGF1 levels was causing a continuous elevation in human collagen production. The lack of a significant difference in myofibrillar protein synthesis rate between patient groups indicates that myofibrillar protein synthesis, and thus muscle size/strength, is not affected by elevated levels of GH/IGF1. Low collagen fibril area was associated with high levels of GH/IGF1 and elevated collagen production in acromegalic patients, which suggests an involvement of GH/IGF1 in the regulation of collagen morphology and thus tissue quality. Despite the limited number of patients and the potential influence of other hormonal factors, the present observation contributes to the understanding of the connective tissue pathways in patients with either high or low GH/IGF1 axis activity. Moreover, these findings strongly suggest that the level of GH/IGF1 is correlated with both the quality and the regenerative capacity of collagen tissue. This is relevant from a clinical perspective given the large number of acromegalic and GHD patients suffering from musculoskeletal disorders.

\section{Declaration of interest}

The authors declare that there is no conflict of interest that could be perceived as prejudicing the impartiality of the research reported.

\section{Funding}

This study was funded by Region Hovedstaden (previously HS foundation), AntiDoping Danmark, Danish Rheumatism Association, Nordea Foundation, Lundbeck Foundation, the Novo Nordisk Foundation, Arvid Nilsson's Foundation and Danish Medical Research Council (271-07-0557 and 271-07-0742).

\section{Acknowledgements}

All the volunteer subjects and patients are sincerely thanked. We would like to express our gratitude to Joan Hansen, Merete Møller, Kirsten Nyborg, Ann-Marie Sedstrøm, Ann-Christina Ronnie Reimann and Mary-Ann Gleie who helped us in collecting and analysing data.

\section{References}

1 Wassenaar MJE, Biermasz NR, van Duinen N, van der Klaauw AA, Pereira AM, Roelfsema F, Smit JWA, Kroon HM, Kloppenburg M \& Romijn JA. High prevalence of arthropathy, according to the definitions of radiological and clinical osteoarthritis, in patients with long-term cure of acromegaly: a case-control study. European Journal of Endocrinology 2009160 357-365. (doi:10.1530/ EJE-08-0845)

2 Giustina A, Mazziotti G \& Canalis E. Growth hormone, insulinlike growth factors, and the skeleton. Endocrine Reviews 200829 535-559. (doi:10.1210/er.2007-0036)

3 Miller A, Doll H, David J \& Wass J. Impact of musculoskeletal disease on quality of life in long-standing acromegaly. European Journal of Endocrinology 2008158 587-593. (doi:10.1530/ EJE-07-0838)

4 Thomas JD \& Monson JP. Adult GH deficiency throughout lifetime. European Journal of Endocrinology 2009161 (Supplement 1) S97-S106. (doi:10.1530/EJE-09-0258)

5 Colao A, Marzullo P, Vallone G, Giaccio A, Ferone D, Rossi E, Scarpa R, Smaltino F \& Lombardi G. Ultrasonographic evidence of joint thickening reversibility in acromegalic patients treated with lanreotide for 12 months. Clinical Endocrinology 199951 611-618. (doi:10.1046/j.1365-2265.1999.00851.x)

6 Bennett R. Growth hormone in musculoskeletal pain states. Current Pain and Headache Reports 20059 331-338. (doi:10.1007/ s11916-005-0009-4)

7 Colao A, Ferone D, Marzullo P \& Lombardi G. Systemic complications of acromegaly: epidemiology, pathogenesis, and management. Endocrine Reviews 200425 102-152. (doi:10. 1210/er.2002-0022)

8 Salmela PI, Juustila H, Pyhtinen J, Jokinen K, Alavaikko M \& Ruokonen A. Effective clinical response to long term octreotide treatment, with reduced serum concentrations of growth hormone, insulin-like growth factor-I, and the amino-terminal 
propeptide of type III procollagen in acromegaly. Journal of Clinical Endocrinology and Metabolism 199070 1193-1201. (doi:10. 1210/jcem-70-4-1193)

9 Sjogren K, Leung KC, Kaplan W, Gardiner-Garden M, Gibney J \& Ho KK. Growth hormone regulation of metabolic gene expression in muscle: a microarray study in hypopituitary men. American Journal of Physiology. Endocrinology and Metabolism 2007293 E364-E371. (doi:10.1152/ajpendo.00054.2007)

10 Sjögren K, Liu J-L, Blad K, Skrtic S, Vidal O, Wallenius V, LeRoith D, Törnell J, Isaksson OGP, Jansson J-O \& Ohlsson C. Liver-derived insulin-like growth factor I (IGF-I) is the principal source of IGF-I in blood but is not required for postnatal body growth in mice. PNAS 199996 7088-7092. (doi:10.1073/pnas.96.12.7088)

11 Velloso CP \& Harridge SD. Insulin-like growth factor-I E peptides: implications for ageing skeletal muscle. Scandinavian Journal of Medicine and Science in Sports 200920 20-27. (doi:10.1111/ j.1600-0838.2009.00997.x)

12 Doessing S, Heinemeier KM, Holm L, Mackey AL, Schjerling P, Rennie M, Smith K, Reitelseder S, Kappelgaard A-M, Rasmussen MH, Flyvbjerg A \& Kjaer M. Growth hormone stimulates the collagen synthesis in human tendon and skeletal muscle without affecting myofibrillar protein synthesis. Journal of Physiology $2010 \mathbf{5 8 8}$ 341-351. (doi:10.1113/jphysiol.2009. 179325)

13 Lange M, Qvortrup K, Svendsen OL, Flyvbjerg A, Nowak J, Petersen MM, ØLgaard K \& Feldt-Rasmussen U. Abnormal bone collagen morphology and decreased bone strength in growth hormone-deficient rats. Bone 200435 178-185. (doi:10.1016/ j.bone.2004.02.025)

14 Bex M \& Bouillon R. Growth hormone and bone health. Hormone Research 200360 (Supplement 3) 80-86. (doi:10.1159/ 000074507)

15 Musarò A, McCullagh K, Paul A, Houghton L, Dobrowolny G, Molinaro M, Barton ER, Sweeney HL \& Rosenthal N. Localized Igf-1 transgene expression sustains hypertrophy and regeneration in senescent skeletal muscle. Nature Genetics 200127 195-200. (doi:10.1038/84839)

16 Lee S, Barton ER, Sweeney HL \& Farrar RP. Viral expression of insulin-like growth factor-I enhances muscle hypertrophy in resistance-trained rats. Journal of Applied Physiology 200496 1097-1104. (doi:10.1152/japplphysiol.00479.2003)

17 Quinn LS, Anderson BG \& Plymate SR. Muscle-specific overexpression of the type 1 IGF receptor results in myoblastindependent muscle hypertrophy via PI3K, and not calcineurin, signaling. American Journal of Physiology. Endocrinology and Metabolism 2007293 E1538-E1551. (doi:10.1152/ajpendo. 00160.2007)

18 Shavlakadze T, Chai J, Maley K, Cozens G, Grounds G, Winn N, Rosenthal N \& Grounds MD. A growth stimulus is needed for IGF-1 to induce skeletal muscle hypertrophy in vivo. Journal of Cell Science 2010123 960-971. (doi:10.1242/jcs.061119)

19 Yarasheski KE, Zachweija JJ, Angelopoulos TJ \& Bier DM. Short-term growth hormone treatment does not increase muscle protein synthesis in experienced weight lifters. Journal of Applied Physiology 199374 3073-3076.

20 Copeland KC \& Nair KS. Acute growth hormone effects on amino acid and lipid metabolism. Journal of Clinical Endocrinology and Metabolism 199478 1040-1047. (doi:10.1210/jc.78.5.1040)

21 Freda PU, Shen W, Reyes-Vidal CM, Geer EB, Arias-Mendoza F, Gallagher D \& Heymsfield SB. Skeletal muscle mass in acromegaly assessed by magnetic resonance imaging and dual-photon X-ray absorptiometry. Journal of Clinical Endocrinology and Metabolism 200994 2880-2886. (doi:10.1210/jc.2009-0026)

22 Widdowson WM, Healy ML, Sonksen PH \& Gibney J. The physiology of growth hormone and sport. Growth Hormone and IGF Research 200919 308-319. (doi:10.1016/j.ghir.2009.04. 023)

23 Nagulesparen M, Trickey R, Davies MJ \& Jenkins JS. Muscle changes in acromegaly. BMJ 19762 914-915. (doi:10.1136/ bmj.2.6041.914)
24 Shakoor SK \& Shalet SM. Effects of GH replacement on metabolism and physical performance in $\mathrm{GH}$ deficient adults. Journal of Endocrinological Investigation 200326 911-918.

25 Klefter O \& Feldt-Rasmussen U. Is increase in bone mineral content caused by increase in skeletal muscle mass/strength in adult patients with GH-treated GH deficiency? A systematic literature analysis European Journal of Endocrinology 2009161 213-221. (doi:10.1530/EJE-09-0160)

26 Norrelund H, Moller N, Nair KS, Christiansen JS \& Jorgensen JO. Continuation of growth hormone (GH) substitution during fasting in GH-deficient patients decreases urea excretion and conserves protein synthesis. Journal of Clinical Endocrinology and Metabolism 200186 3120-3129. (doi:10.1210/jc.86.7.3120)

27 Burt MG, Gibney J, Hoffman DM, Umpleby AM \& Ho KK. Relationship between $\mathrm{GH}$-induced metabolic changes and changes in body composition: a dose and time course study in GH-deficient adults. Growth Hormone and IGF Research 200818 55-64. (doi:10.1016/j.ghir.2007.07.005)

28 Movin T. Tendon tissue sampling. Scandinavian Journal of Medicine and Science in Sports 200010 368-371. (doi:10.1034/ j.1600-0838.2000.010006368.x)

29 Bergstrom J. Percutaneous needle biopsy of skeletal muscle in physiological and clinical research. Scandinavian Journal of Clinical and Laboratory Investigation 197535 609-616.

$30 \mathrm{Wu}$ JH, Hong PY \& Liu WT. Quantitative effects of position and type of single mismatch on single base primer extension. Journal of Microbiological Methods 200977 267-275. (doi:10. 1016/j.mimet.2009.03.001)

31 Babraj J, Cuthbertson DJ, Rickhuss P, Meier-Augenstein W, Smith K, Bohé J, Wolfe RR, Gibson JN, Adams C \& Rennie MJ. Sequential extracts of human bone show differing collagen synthetic rates. Biochemical Society Transactions 200230 61-65. (doi:10.1042/BST0300061)

32 Larsen JO. Stereology of nerve cross sections. Journal of Neuroscience Methods 199885 107-118. (doi:10.1016/S01650270(98)00129-0)

33 Magnusson SP, Qvortrup K, Larsen JO, Rosager S, Hanson P, Aagaard P, Krogsgaard M \& Kjaer M. Collagen fibril size and crimp morphology in ruptured and intact Achilles tendons. Matrix Biology 200221 369-377. (doi:10.1016/S0945-053X(02) 00011-2)

34 Westwood M, Gibson JM, Davies AJ, Young RJ \& White A. The phosphorylation pattern of insulin-like growth factor-binding protein-1 in normal plasma is different from that in amniotic fluid and changes during pregnancy. Journal of Clinical Endocrinology and Metabolism 199479 1735-1741. (doi:10.1210/jc.79.6.1735)

35 Wolfe RR \& Chinkes DL. Isotope Tracers in Metabolic Research: Principles and Practice of Kinetic Analysis, edn 2, ch. 6, pp 326-341. John Wiley \& Sons, Inc., 2005.

36 Katznelson L. Alterations in body composition in acromegaly. Pituitary 200912 136-142. (doi:10.1007/s11102-008-0104-8)

37 Ohlsson C, Bengtsson BA, Isaksson OG, Andreassen TT \& Slootweg MC. Growth hormone and bone. Endocrine Reviews 199819 55-79. (doi:10.1210/er.19.1.55)

38 Abrahamsson SO. Similar effects of recombinant human insulinlike growth factor-I and II on cellular activities in flexor tendons of young rabbits: experimental studies in vitro. Journal of Orthopaedic Research 199715 256-262. (doi:10.1002/jor.1100150215)

39 Banes AJ, Tsuzaki M, Hu P, Brigman B, Brown T, Almekinders L, Lawrence WT \& Fischer T. IGF-I and mechanical load stimulate DNA synthesis in avian tendon fibroblasts in vitro. Journal of Biomechanics 199528 1505-1513. (doi:10.1016/0021-9290 (95)00098-4)

40 Murphy DJ \& Nixon AJ. Biochemical and site-specific effects of insulin-like growth factor I on intrinsic tenocyte activity in equine flexor tendons. American Journal of Veterinary Research $1997 \mathbf{5 8}$ 103-109.

41 Choy VE, Kyparos A, Vailas AC, Crenshaw TD \& Martinez DA. The biphasic response of porcine tendon to recombinant porcine growth hormone. Growth Hormone and IGF Research 200515 39-46. (doi:10.1016/j.ghir.2004.11.003) 
42 Wilson VJ, Rattray M, Thomas CR, Moreland BH \& Schulster D. Growth hormone increases IGF-I, collagen I and collagen III gene expression in dwarf rat skeletal muscle. Molecular and Cellular Endocrinology 1995115 187-197. (doi:10.1016/0303-7207 (95)03690-3)

43 Fairfield WP, Sesmilo G, Katznelson L, Pulaski K, Freda PU, Stavrou S, Kleinberg D \& Klibanski A. Effects of a growth hormone receptor antagonist on bone markers in acromegaly. Clinical Endocrinology 200257 385-390. (doi:10.1046/j.1365-2265. 2002.01624.x)

44 Bollerslev J, Moller J, Thomas S, Djoseland O \& Christiansen JS. Dose-dependent effects of recombinant human growth hormone on biochemical markers of bone and collagen metabolism in adult growth hormone deficiency. European Journal of Endocrinology 1996135 666-671. (doi:10.1530/eje.0. 1350666)

45 Parkinson C, Kassem M, Heickendorff L, Flyvbjerg A \& Trainer PJ. Pegvisomant-induced serum insulin-like growth factor-I normalization in patients with acromegaly returns elevated markers of bone turnover to normal. Journal of Clinical Endocrinology and Metabolism 200388 5650-5655. (doi:10.1210/jc.2003030772)

46 Allanore Y, Borderie D, Lemarechal H, Cherruau B, Ekindjian OG \& Kahan A. Correlation of serum collagen I carboxyterminal telopeptide concentrations with cutaneous and pulmonary involvement in systemic sclerosis. Journal of Rheumatology 2003 30 68-73.

47 Eliakim A, Scheett TP, Newcomb R, Mohan S \& Cooper DM. Fitness, training, and the growth hormone $\rightarrow$ insulin-like growth factor I axis in prepubertal girls. Journal of Clinical Endocrinology and Metabolism 200186 2797-2802. (doi:10.1210/jc.86.6. 2797)

48 Rechler MM \& Clemmons DR. Regulatory actions of insulin-like growth factor-binding proteins. Trends in Endocrinology and Metabolism 19989 176-183. (doi:10.1016/S1043-2760(98) 00047-2)

49 Jarkovská Z, Rosická M, Marek J, Hna V, Weiss V, Justová V, Lacinová Z, Haluzík M \& Krsek M. Plasma levels of total and active ghrelin in acromegaly and growth hormone deficiency. Physiological Research 200655 175-181.
50 Kim HJ, Kwon SH, Kim SW, Park DJ, Shin CS, Park KS, Kim SY, Cho BY \& Lee HK. Diagnostic value of serum IGF-I and IGFBP-3 in growth hormone disorders in adults. Hormone Research 200156 117-123. (doi:10.1159/000048103)

51 Kim H, Barton E, Muja N, Yakar S, Pennisi P \& Leroith D. Intact insulin and insulin-like growth factor-I receptor signaling is required for growth hormone effects on skeletal muscle growth and function in vivo. Endocrinology $2005 \quad 146 \quad 1772-1779$. (doi:10.1210/en.2004-0906)

52 Schlechter NL, Russell SM, Spencer EM \& Nicoll CS. Evidence suggesting that the direct growth-promoting effect of growth hormone on cartilage in vivo is mediated by local production of somatomedin. PNAS 198683 7932-7934. (doi:10.1073/pnas. 83.20.7932)

53 Abrahamsson SO, Lundborg G \& Lohmander LS. Recombinant human insulin-like growth factor-I stimulates in vitro matrix synthesis and cell proliferation in rabbit flexor tendon. Journal of Orthopaedic Research 19919 495-502. (doi:10.1002/jor.1100090405)

54 Delaughter MC, Taffet GE, Fiorotto ML, Entman ML \& Schwartz RJ. Local insulin-like growth factor I expression induces physiologic, then pathologic, cardiac hypertrophy in transgenic mice. FASEB Journal 199913 1923-1929.

55 Mukherjee A \& Shalet SM. The value of IGF1 estimation in adults with GH deficiency. European Journal of Endocrinology 2009161 (Supplement 1) S33-S39. (doi:10.1530/EJE-09-0247)

56 Schonherr E, Sunderkotter C, Iozzo RV \& Schaefer L. Decorin, a novel player in the insulin-like growth factor system. Journal of Biological Chemistry 2005280 15767-15772. (doi:10.1074/jbc. M500451200)

57 Canty EG \& Kadler KE. Procollagen trafficking, processing and fibrillogenesis. Journal of Cell Science 2005118 1341-1353. (doi:10.1242/jcs.01731)

58 Hameed M, Harridge SD \& Goldspink G. Sarcopenia and hypertrophy: a role for insulin-like growth factor-1 in aged muscle? Exercise and Sport Sciences Reviews 200230 15-19. (doi:10.1097/00003677-200201000-00004)

Received 11 September 2010

Accepted 21 September 2010 